Ann. Biol. anim. Bioch. Biophys., 1978, 18 (2 B), 565-572.

\title{
Hormonal regulation of Sertoli cell function in the rat
}

\author{
by V. HANSSON, K. PURVIS, E. M. RITZÉN, F. S. FRENCH ** \\ Institute of Pathology, University of Oslo, \\ Rikshospitalet, Oslo 1, Norway \\ * Pediatric Endocrinology Unit, Karolinska Sjukhuset, \\ Stockholm, Sweden \\ ** Department of Pediatrics, Laboratory of Reproductive \\ Biology, University of North Carolina, Chapel Hill, U. S. A.
}

Summary. The Sertoli cell is the main regulator of spermatogenesis, the function of wich is regulated by FSH and androgen. It seems reasonable that most, if not all, the hormonal effects on spermatogenesis are mediated through the Sertoli cell. Whether or not androgens also act directly on the germinal cells remains to be established.

\section{Introduction.}

The hormonal regulation of spermatogenesis involves an interplay of sex steroids and pituitary gonadotrophic hormones acting on specific cells of the testis. Several reviews have brought together earlier work on spermatogenesis (Steinberger, 1971 ; Courot ef al., 1970 ; Bishop and Walton, 1960 ; Clermont and Harvey, 1967). Recent progress has led to the identification of target cells for pituitary hormones and steroid hormones within the testis and to the elucidation of molecular mechanisms for hormone action. In his review of the hormonal control of mammalian spermatogenesis, Steinberger (1971) concluded that «knowledge of the biochemical parameters of the hormonal action on spermatogenesis is too meager even for a limited attempt to formulate a working hypothesis ». During the last five years, however, much has been learned about how hormones regulate the functions of cells within the testis, and in particular hormonal control of the Sertoli cell. Recent studies have shown that most, if not all the hormonal stimuli to spermatogenesis, may be mediated by the Sertoli cell.

FSH.

Although biochemical effects of FSH on the testis were established early, there have until recently been few attempts to localize the $\mathrm{FSH}$-sensitive target cells. In 1965 Murphy proposed that an injection of FSH increased the secretory activity of Sertoli cells, and in fact, suggested that this effect might be used as a bioassay for the 
hormone in the testis (Murphy, 1965a, b). Subsequently, studies from Mancini and colleagues yielded evidence that FSH, conjugated to electron-dense substances such as ferritin or isothiocyanate, interacted with the supporting Sertoli cells and/or spermatogonia (Mancini et al., 1967 ; Castro et al., 1970). All of these observations are compatible with current views that the Sertoli cell is an FSH target cell in the testis. The importance of these early studies was diminished, however, by disadvantages inherent in the techniques used. For example, the hormones injected were only partially purified preparations, and their contaminants may have caused nonspecific localization. Hormones were labeled directly with fluorescent dyes or with ferritin (molecular. weight of about 6000000 ) using a conjugation process which caused more than 50 p. 100 loss of the biological activity of the FSH preparation. In addition steric hindrance may have interfered with normal binding and transport to the target cells within the testis. Finally, extremely high doses were injected in order to obtain clear localization of FSH in the testis, a fact that casts further doubt on the specificity of the results.

Midgley and coworkers (1972) carried out light microscopical autoradiography studies after the topical application of ${ }^{125}$-FSH to unfixed frozen sections. They confirmed that FSH localizes within the seminiferous tubules, although cellular or subcellular localization was not established (Desjardins ef al., 1974).

Several lines of research during the last four years have established that Sertoli cells are the target cells for FSH in the testis. One important discovery was the demonstration and characterization of testicular androgen-binding protein (ABP) (Hansson, 1972 ; Hansson ef al., 1973 ; French and Ritzén, 1973a, b). ABP is produced by the Sertoli cell and secreted into the testicular fluid (for review, see Hansson et al., 1975a and 1976b). It disappears both from the testis and epididymis after hypophysectomy and reappears after treatment with pituitary gonadotropins (Hansson et al., 1973, 1974 ; Fritz ef al., 1974). In the immature rat, ABP in the caput epididymis decreases to undetectable levels within 5 days after hypophysectomy, while in the mature rat a somewhat slower decline has been found (Hansson et al., 1975a). Within 24 hours after injection of FSH to immature hypophysectomized rats, ABP accumulation can be measured both in the testis and caput epididymis. The levels in the epididymis reach a plateau within 2-4 days, and further treatment does not give a proportional increase in $A B P$ content. When hypophysectomized rats are injected with different doses of FSH, ABP concentration in the caput epididymis is dose-dependent. The sensitivity of this ABP response is comparable to that of the ovarian weight augmentation assay (Steelman-Pohley assay) (Hansson ef al., 1975a). Sertoli cell response to FSH administration was found to be specific when measured by the amount to $A B P$ in the epididymis. Other pituitary hormones, androgens $(2 \mathrm{mg} / 3$ days $)$ or estrogen $(500 \mu \mathrm{g} / 3$ days) had no effect when administered for the same length of time (Hansson ef al., 1975). Furthermore, the ability of the different FSH preparations to induce ABP secretion from Sertoli cells correlates very well with their ability to stimulate ovarian weight increase in the Steelman-Pohley assay (Hansson ef al., 1975a; Hansson ef al. $1976 b$ ). These findings provided evidence that FSH was important in stimulating Sertoli cell production and secretion of ABP in hypophysectomised rats.

All of the studies on FSH effects on ABP suggest that the Sertoli cell is a target cell for FSH. Recent experiments using Sertoli cell cultures confirm this conclusion. Several effects of FSH have been demonstrated using cultured Sertoli cells, including 
incorporation of ${ }^{3} \mathrm{H}$-thymidine into nuclear DNA (Griswold et al., 1975), characteristic morphological changes (Tung and Fritz, 1975), and stimulation of the conversion of testosterone to estradiol-17 $\beta$ (Armstrong ef al., 1975). Several laboratories have shown that FSH stimulates the formation of cyclic AMP in isolated Sertoli cells in culture (Fritz ef al., 1975 ; Steinberger, 1975). Moreover, Means and Huckins (1974) demonstrated specific binding of ${ }^{3} \mathrm{H}$-labeled $\mathrm{FSH}$ to membrane receptors of seminiferous tubules devoid of germ cells with a subsequent stimulation of cyclic AMP formation, protein kinase and mRNA formation. Finally, FSH stimulation of ABP production in vitro, both in organ culture (Ritzén ef al., 1975) and in cell cultures (Fritz et al., 1975 ; Steinberger, 1975) has been reported. Thus, independent studies in several laboratories now strongly suggest that the Sertoli cell is a main target cell for FSH in the testis. It is less clear, however, whether additional target sites exist in other cells (immature Leydig cells ?) of the testis or if all the testicular effects of FSH can be accounted for by the responses induced in the Sertoli cell.

For a more detailed description of FSH action on the Sertoli cell, two recent books should be consulted (Dufau and Means, 1974 ; French et al., 1975).

\section{Androgens.}

The Sertoli cell appears to be a target cell not only for $\mathrm{FSH}$, but also for androgens (Hansson ef al., 1974 ; Hansson ef al., 1976b ; Ritzén ef al., 1975). The sensitivity of the Sertoli cell to FSH, as measured by ABP response, decreases dramatically after hypophysectomy, but can be maintained by treatment with high doses of testosterone propionate (Hansson et al., 1974). When hypophysectomized immature rats are treated with $2 \mathrm{mg}$ testosterone daily beginning at day 1 after hypophysectomy, Sertoli cell sensitivity to FSH is increased compared to that seen in the 2-day hypophysectomized controls (Hansson ef al., 1974). Thus, in prepubertal animals, androgens dramatically influence the sensitivity of the Sertoli cell to FSH. The secretory function of the Sertoli cell during this time period is therefore dependent on FSH and androgens.

Another series of studies also points to the Sertoli cell as a target cell for androgens. When various doses of testosterone propionate (TP 10-10000 $\mu \mathrm{g} /$ day) were given daily to 21-day old rats for 10 day, a biphasic effect was observed both on testis weight and on ABP levels in the testis and epididymis (Weddington et al., 1976). At low doses $(10-100 \mu \mathrm{gTP} /$ day), there was a reduction in testis weight as well as in ABP levels. This was accompanied by a drecrease in serum FSH and $\mathrm{LH}$. At higher doses of TP (200-10000 $\mu \mathrm{g})$, there was a stimulation both of testis weight and ABP levels in spite of suppressed serum gonadotropins. These effects of testosterone propionate on Sertoli cell secretion of ABP further support the idea that the Sertoli cell, in addition to being a target cell for $\mathrm{FSH}$, is also a target cell for androgens (Hansson et al., 1976a, b).

In subsequent experiments we have injected varying doses of DHTP and $5 \alpha$ androstane- $3 \alpha-17 \beta$-diol (ADIOL) in order to better understand which androgen metabolite is most active in stimulating Sertoli cell function (Purvis et al., 1977). We found that both steroids gave a dose-dependent suppression of both FSH and LH. This was accompanied by a fall in intratesticular androgens as well as by a decreased Sertoli cell secretion of ABP into the epididymis. At high doses of DHTP and ADIOL, 
there is a direct stimulation of testis weight and epididymal ABP, in spite of suppressed gonadotropins. There is a excellent correlation between the intratesticular levels of DHT and ABP secretion. Furthermore, these data show that ADIOL does not stimulate the Sertoli cell without its conversion to DHT; at doses of DHTP and ADIOL whic: give a normal intratesticular concentration of ADIOL, testis weight and epididymal ABP are completely suppressed. In addition, it can be concluded from these studies that $T$ is not essential for normal Sertoli cell function and spermatogenesis, as long as a sufficient amount of DHT is present in the testis (Purvis et al., 1977).

We have also noted that androgen alone, in the absence of the pituitary, can maintain Sertoli cell secretory function in hypophysectomized rats when it is given immediately after hypophysectomy (Hansson ef al., 1974, Hansson et al., 1976b). That androgen alone is capable of maintaining ABP production is reminiscent of the early observation that androgen is capable of maintaining spermatogenesis. If suggests that when androgen treatment maintains spermatogenesis it also maintains Sertoli cell function.

We looked to see if androgen alone was capable of initiating Sertoli cell secretory function when treatment following hypophysectomy was delayed until the seminiferous tubular epithelium was regressed. Rats were hypophysectomized at 28 days of age and 10 days later $4 \mathrm{mg}$ testosterone propionate were given daily for 8 days. No increase in ABP was detected in the caput epididymis, and only slightly increased levels of ABP were found in the testis. Under the same conditions, the Sertoli cell remained responsive to FSH (Hansson et al., 1976a). The finding that TP alone is less effective in initiating than maintaining Sertoli cell function may explain why it is less capable of initiating spermatogenesis under similar conditions. A similar discrepancy between the ability of androgens to maintain Sertoli cell secretion and its inability to reinitiate Sertoli cell secretion of ABP after posthypophysectomy regression has been demonstrated in adult hypophysectomized rats (Hansson et al., 1976a, b). These findings reemphasize the importance of the Sertoli cell in spermatogenesis. Thus it seems that after a long period of hypophysectomy, the Sertoli cell becomes relatively insensitive to androgen, at least with respect to ABP secretion (Hansson ef al., 1975a, $1976 a, b)$. It is not known which factor or factors are needed to restore normal androgen sensitivity of the Sertoli cell.

In one set of experiments, we treated adult animals after 60 days of posthypophysectomy regression with FSH for 5 days in order to obtain maximum ABP secretion before continuing the treatment with testosterone propionate alone (Hansson ef al., 1975b). The question asked was : At the time when the secretory function of the Sertoli cell is already established by FSH, will testosterone then be capable of taking over and maintaining this secretory function? From our studies this does not seem to be the case (Hansson ef al., 1975b). After stopping FSH treatment, there was a gradual decrease in ABP content both in the testis and in the epididymis, in spite of continuing testosterone treatment, indicating that testosterone propionate alone was not capable of maintaining the secretory function of Sertoli cells at the level established by FSH under these experimental conditions. This could be due to the fact that 5 days of FSH treatment is too short a time for restoring the components which are necessary for optimal androgen sensitivity. However, the possibility that factors other than FSH might be needed to normalize Sertoli cell response to androgens cannot be excluded. 
Since androgens have such marked effects on the Sertoli cell, as measured by ABP production, it was of great interest to determine if ABP was present in the androgen-insensitive (Stanley Gumbreck) rat (Tfm rat). Surprisingly, the Tfm rat testis contained almost 10 times as much ABP as the normal littermates when calculated per $\mathrm{mg}$ of protein. Also, when calculated as ABP per testis, the Tfm rats contained more $A B P$ than the normal rat. This clearly showed that $A B P$ is formed even in the absence of androgen stimulation. Whether or not ABP production in the Tfm testis is higher or lower than that of the normal littermates was studied in vitro by incubating the testes from Tfm rats and their normal littermates in short-time organ cultures as described previously (Ritzén ef al., 1975). Following the initial release of preformed $A B P$, the production rate of ABP in the Tfm testis between 4 and 20 hours of incubation, was only one-third of that in the normal littermates (calculated as ABP production per testis). These studies therefore indicate that ABP production in the Sertoli cell of the Tfm testis is lower than in those of normal littermates. The most likely explanation for this is that androgen stimulation of the Tfm testis is insufficient to maintain the normal secretory function of the Sertoli cells. The high content of ABP in the testes of Tfm rats as compared to normal rats must result from the absence of an epididymis. A block in the outflow of testicular fluid would allow a large amount of ABP to accumulate in the testis even at a low production rate.

Although these in vivo studies pointed to the Sertoli cell as a target cell for androgens, the possibility remained that the hormone injected in vivo might exert its effect indirectly through other organs. Ritzén ef al. (1975) have now demonstrated that ABP synthesis in testis organ culture can be stimulated by testosterone. Thus, testosterone acts directly on the testis to stimulate Sertoli cell production of ABP.

Another indication that androgens are acting directly on the Sertoli cell has come from the demonstration that androgen receptors appear to be localizedto these cells (Sar ef al., 1975 ; Wilson and Smith, 1975). Androgen receptors in rat testis have physicochemical properties similar to receptors in rat ventral prostate and epididymis and different from ABP. Moreover, Wilson and French (1976) have shown these androgen receptors to have nearly identical binding properties in vitro. In each organ the receptors are specific for testosterone and dihydrotestosterone and bind dihydrotestosterone with slightly higher affinity than testosterone. Androgen receptors in testis are absent in the rat with the syndrome of testicular feminization as demonstrated both by biochemical and autoradiographic techniques (Sar ef al., 1975 ; Smith et al., 1975). The fact that the hormonal requirement for normal Sertoli function is identical to that needed for normal spermatogenesis, stresses the importance of the Sertoli cell in the regulation of the spermatogenic process (Hansson et al., 1976b).

A recent publication by Lyon et al. (1975) may be interpreted as evidence that androgen does not act directly on germ cells. These workers made male mice chimaeric for androgen resistant $(\mathrm{Tfm} / \mathrm{y})$ and normal $(+/ \mathrm{y})$ genotypes by the technique of embryo aggregation. They determined if spermatozoa were formed from the $\mathrm{Tfm} / \mathrm{y}$ component and the extent to which these spermatozoa were fertile (Lyon et al., 1975). Out of the 57 chimaeric animals produced, two fertile males were of the $\mathrm{Tfm} / \mathrm{y} \leftrightarrow+/ \mathrm{y}$ genotype and both produced numerous offspring from their $\mathrm{Tfm} / \mathrm{y}$ component. This indicated that the requirement for testosterone in spermatogenesis does not involve the cell-autonomous action of the Tfm locus in the germ cells. If the Tfm locus is not 
involved in androgen action on the germ cells, the androgen message to the germ cells may be mediated through the Sertoli cell that in this chimera may have $a+/ y$ genotype and hence be androgen-responsive. These data support, but do not conclusively prove, that the response to androgen of the seminiferous epithelium is entirely mediated by testicular somatic cells (Lyon et al., 1975).

From the current concept of androgen action in mammalian cells, it is difficult to find a role for steroid hormones in stimulating more mature types of germinal cells like the late spermatids and spermatozoa. Steroid-receptor complexes are believed to act primarily through transcription and secondarily on protein synthesis. In haploid cells without transcriptional capability, new concepts of androgenic hormone action need to be established before androgen action on mature germ cells can become an attractive theory.

27 e Congrès international des Sciences physiologiques, Symposium " Germ and somatic cell interaction " Paris, 21-23 juillet 1977.

Résumé. La régulation hormonale de la spermatogenèse met en jeu à la fois les hormones gonadotropes et les stéroïdes sexuels. Nous faisons ici une revue des rôles respectifs de FSH et des androgènes sur l'épithélium séminifère et plus particulièrement, sur les cellules de Sertoli. La synthèse d'ABP par les cellules de Sertoli esł sous contrôle à la foi de $\mathrm{FSH}$ et des androgènes.

La concentration en ABP de la tête de l'épididyme de rat hypophysectomisé est liée à la dose de FSH injectée. Mais, la réponse des cellules de Sertoli à FSH dépend de la présence de testostérone. Par ailleurs, on obtient une réponse « biphasique » du poids testiculaire de raton prépubère après injections à des doses croissantes de propionate de testostérone. A doses très élevées, les niveaux d'hormones gonadotropes sont très bas ; il y a cependant une stimulation du poids testiculaire et de la synthèse d'ABP.

L'androstanediol et la dihydrotestostérone ont une action comparable sur la cellule de Sertoli. Après hypophysectomie, s'il n'y a pas eu régression, le traitement par la testostérone appliquée dès l'opération maintient la spermatogenèse de l'adulte.

Chez le rat adulte hypophysectomisé, un traitement de 5 jours par la FSH suivi d'un traitement par la testostérone ne maintient pas la sécrétion d'ABP au niveau obtenu par la FSH.

Chez les rats TFm, sans récepteurs aux androgènes, il y a une concentration 10 fois plus élevée d'ABP/mg de protéine.

Des récepteurs aux androgènes ont été mis en évidence dans le cytoplasme Sertolien. Ils sont absents chez les rats TFm. Leurs présences dans les cellules germinales restent discutées.

\section{References}

ARMSTRONG D. T., MOON Y. S., FRITZ I. B., DORRINGTON J. H., 1975. Synthesis of estradiol$17 \beta$ by Sertoli cells in culture, 85-96. In FRENCH F. S., HANSSON V., RITZÉN E. M., Hormonal regulation of spermatogenesis Plenum Press, N. Y.

BISHOP M. W. H., WALTON A., 1970. Spermatogenesis and the structure of mammalian spermatozoa. In PARKES A. S. Marshall's Physiology of reproduction, Vol. I, 1-129, Longman's Green, N. Y.

CASTRO A. E., SEIGUER A. C., MANCINI R. E., 1970. Electron microscopic study of the localization of labelled gonadotropins in the Sertoli cells and Leydig cells of the rat testis. Proc. Soc. exp. Biol. Med., 133, 582-586.

CLERMONT Y., HARVEY S. C., 1967. Effects of hormones on spermatogenesis in the rat. Ciba Found. Colloc. Endocrinol. 16, 173-189. 
COUROT M., HOCHEREAU de REVIERS M. T., ORTAVANT R., 1970. Spermalogenesis, 339-432. In JOHNSON A. D., GOMES W. R., VANDEMARK N. L., The testis. Acad. Press, N. Y.

DESJARDINS C., ZELEZNIK A. J., MIDGLEY A. R., REICHERT L. E., 1974. In vitro binding and autoradiographic localization of hCG and FSH in rat testis during development, 221-235. In DUFAU M. L., MEANS A. R., Hormone binding and target cell activation in the testis. Plenum Press, N. Y.

DUFAU M. L., MEANS A. R., 1974. Hormone binding and target cell activation in the testis. Plenum Press, N. Y.,

FRENCH F. S., HANSSON V., RITZÉN E. M., NAYFEH S. N., 1975. Hormonal regulation of spermatogenesis. Plenum Press, N. Y.

FRENCH F. S., RITZÉN E. M., 1973a. Androgen binding protein (ABP) in efferent duct fluid of rat testis. J. Reprod. Fert., 32, 479-483.

FRENCH F. S., RITZÉN E. M. 1973b. A high affinity androgen binding protein (ABP) in rat testis : evidence for secretion into efferent duct fluid and absorption by the epididymis. Endocrinology, 93, 88-95.

FRITZ I. B., KOPEC B., LAM K., VERNON R. G., 1974. Effect of FSH on levels of androgen binding protein in the testis, 311-327. In DUFAU M. L., MEANS A. R., Hormone binding and torget cell activation in the testis. Plenum Press, N. Y.

FRITZ I. B., LOUIS B. G., TUNG P. S., GRISWOLD M., ROMMERTS F. G., DORRINGTON J. H., 1975. Biochemical responses of cultured Sertoli cell-enriched preparations to FSH and dibutyryl c-AMP, 367-382. In FRENCH F. S., HANSSON V., RITZÉN E. M., NAYFEH S. N., Hormonal regulation of spermatogenesis. Plenum Press, N. Y.

GRISWOLD M., MABLY E., FRITZ 1. B., 1975. Stimulation by FSH and dibutyryl c-AMP of incorporation of ${ }^{3} \mathrm{H}$-thymidine into nuclear DNA of cultured Sertoli cell-enriched preparations from immature rats, 413-420. FRENCH F. S., HANSSON V., RITZÉN E. M., NAYFEH S. N. Hormonal regulation of spermatogenesis. Plenum Press, N. Y.

HANSSON V., 1972. Further characterization of the $5 \alpha$-DHT binding protein in the epididymal cytosol fraction. In vitro studies. Steroids, 20, 575-596.

HANSSON V., REUSH E., TRYGSTAD O., TORGERSEN O., FRENCH F. S., RITZEN E. M., 1973. FSH stimulation of testicular androgen binding protein. Noture, New Biology, 246, 56-58.

HANSSON V., FRENCH F. S., WEDDINGTON S. C., NAYFEH S. N., RITZÉN E. M., 1974. FSH stimulation of testicular androgen binding protein (ABP) : androgen « priming 》 increases the response to FSH, 287-290. In DUFAU M. L., MEANS A. R., Hormone binding and target cell activation of the testis. Plenum Press, N. Y.

HANSSON V., RITZÉN E. M., FRENCH F. S., NAYFEH S. N., 1975a. Androgen receptor and transport mechanisms in the testis and epididymids. In HAMILTON D. W., GREEP R. O., Handbook of Physiology, Vol. 5, sect. 7, 173-201. Amer. Physiol. Soc.

HANSSON V., WEDDINGTON S. C., NAESS O., ATTRAMADAL A., FRENCH F. S., KOTITE N., NAYFEH S. N., RITZÉN E. M., 1975b. Testicular androgen binding protein : a parameter of Sertoli cell secretory function, 323-336. In FRENCH F. S., HANSSON V., RITZÉN E. M., NAYFEH S. N., Hormonal regulation of spermatogenesis. Plenum Press, N. Y.

HANSSON V., PURVIS K., CALANDRA R., FRENCH F. S., KOTITE N., NAYFEH S. N., RITZÉN E. M., HAGENAS L., 1976a. The hormonal specificity of the production and secretion of ABP from Sertoli cells, 410-416. In JAMES V. H. T. Excerpla Med. int. Congr Ser. no. 402, Amsterdam.

HANSSON V., CALANDRA R., PURVIS K., RITZENN E. M., FRENCH F. S., 1976 b. Hormonal regulation of spermatogenesis. Vitam. Horm., 34, 187-213.

LYON M. F., GLENISTER P. H., LAMOREUX M. L., 1975. Normal spermatozoa from androgen resistant germ cells of chimaeric mice and the role of androgen in spermatogenesis. Nafure, 258, 620-622.

MANCINI R. E., CASTRO A., SEIGUER A. C., 1967. Histologic localization of FSH and LH in the rat testis. J. Histochem., 15, 516-525.

MEANS A. R., HUCKINS C., 1974. Coupled events in the early biochemical actions of FSH on the Sertoli cells of the testis, 145-165. In DUFAU M. L., MEANS A. R., Hormone binding and target cell activation in the testis. Plenum Press, N. Y.

MIDGLEY A. R., J., 1972. Gonadotropin binding to frozen sections of ovarian tissue, 248-260. In SAXENA B. B., BELING C. G., GANDY H. M., Gonodotropins. Wiley-Interscience, N. Y. 
MURPHY H. D., 1965a. Sertoli cell stimulation following intratesticular injections of FSH in the hypophysectomized rat. Proc. Soc. exp. Biol. Med., 118, 1202-1205.

MURPHY H. D., 1965b. Intratesticular assay of FSH in hypophysectomized rats. Proc. Soc. exp. Biol . Med. 120, 671-675.

PURVIS K., CALANDRA R., HAUG E., HANSSON V., 1977. $5 \alpha$-Reduced androgens and testicular function in the immature rat : Effects of DHT and $5 \alpha$-androstane-3 $\alpha, 17 \beta$-diol. Mol. cellul., Endocr., 7, 203-219.

RITZEN E. M., HAGENAS L., HANSSON V., FRENCH F. S., 1975. In vitro synthesis of testicular androgen binding protein (ABP) : Stimulation by FSH and androgen, 353-366. In FRENCH F. S., HANSSON V., RITZÉN E. M., NAYFEH S. N., Hormonal regulation of spermatogenesis. Plenum Press, N. Y.

SAR M., STUMPF W. E., MCLEAN W. S., SMITH A. A., HANSSON V., NAYFEH S. N., FRENCH F. S., 1975. Localization of androgen target cells in the rat testis : autoradiographic studies, 311 319. In FRENCH F. S., HANSSON V., RITZEN E. M., NAYFEH S. N., Hormonal regulation of spermatogenesis. Plenum Press, N. Y.

SMITH A. A., MCLEAN W. S., NAYFEH S. N., FRENCH F. S., HANSSON V., RITZÉN E. M., 1975. Androgen receptors in rat testis 257-280. In FRENCH F. S., HANSSON V., RITZÉN E. M. , NAYFEH S. N., Hormonal regulation of spermatogenesis. Plenum Press, N. Y., PP. 257-280.

STEINBERGER E., 1971. Hormonal control of mammalian spermatogenesis. Physiol. Rev., 51, 1-22.

STEINBERGER E., 1975. Hormonal regulation of the seminiferous fubule function, 337-352. In FRENCH F. S., HANSSON V., RITZÉN E. M., NAYFEH S. N., Hormonal regulation of spermatogenesis. Plenum Press, N. Y.

TUNG P. S., FRITZ I. B., 1975. Follicle stimulating hormone and cyclic AMP directed changes in ultrastructure and properties of cultured Sertoli cell enriched preparations : comparison with cultured peritubular cells, 495-508. In FRENCH F. S., HANSSON V., RITZEN E. M., NAYFEH S. N., Hormonal regulation of spermatogenesis. Plenum Press, N. Y.

WILSON E. M., FRENCH F. S., 1976. Binding properties of androgen receptors. Evidence for identical receptors in rat testis, epididymis and prostate. J. Biol. Chem., 251, 5620-5629.

WILSON E. M., SMITH A. A., 1975. Localization of androgen receptors in rat testis : biochemical studies, 281-286. In FRENCH F. S., HANSSON V., RITZEN E. M., NAYFEH S. N., Hormonal regulation of spermatogenesis. Plenum Press, N. Y.

WEDDINGTON S. C., HANSSON V., PURVIS K., VARAAS T., VERJANC H. L., EIK-NES K. B., RYAN W. H., FRENCH F. S., RITZEN E. M., 1976. Biphasic effect of testosterone propionate on Sertoli cell secretory function. Mol. cellul. Endocr., 5, 137-145. 